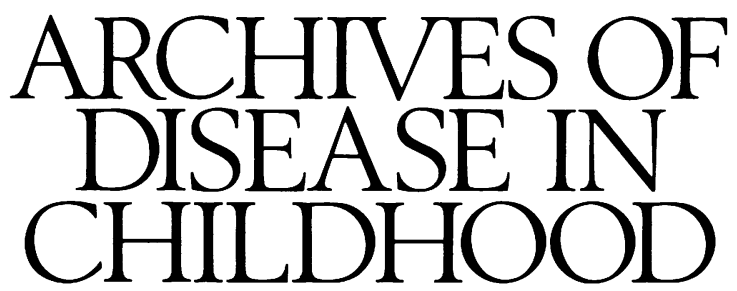

The fournal of the British Paediatric Association

\title{
Annotations
}

\section{Immunological studies on type 1 diabetes in identical twins}

Type 1 diabetes is a disease in which the insulin-producing islet $\beta$ cells are selectively destroyed. It has a peak onset around puberty and the incidence within Europe ranges from 40 to four cases/100000/year along a north-south gradient from Scandinavia to Greece, punctuated with occasional 'hot-spots' such as Sardinia. ${ }^{1}$ In the UK, the incidence is estimated at some 16 cases/100000/year and appears to be rising. ${ }^{2}$

Type 1 diabetes arises on a distinct genetic background. While the disease may be polygenic, attention has focused on the HLA system; some class II alleles (HLA DR3 and DR4 serotypes, or genes encoding DQ molecules such as DQA $\left.1{ }^{\star} 0301 / \mathrm{DQB} 1{ }^{\star} 0302\right)$ impart a high risk of developing diabetes, while others (DR2, DQA1 ${ }^{\star} 0102 / \mathrm{DQB} 1{ }^{\star} 0602$ ) provide protection. ${ }^{3}$

Genetically identical (monozygotic) twins of type 1 diabetic patients carry a higher relative risk (approximately 230) of becoming diabetic than does an individual possessing any one of the HLA markers described above, yet only one third of such twins will develop the disease. ${ }^{45}$ In other words, environmental factors must have an important influence on the development of the disease.

The detection of a mononuclear cell (lymphocyte and macrophage) infiltrate within and around islet remnants at diagnosis indicates that the immune system has a role in the pathogenesis of the disease. ${ }^{6}$ Circulating islet-specific autoantibodies, ${ }^{7}$ abnormal distributions of immunoregulatory ${ }^{89}$ and activated $\mathrm{T}$ lymphocytes, ${ }^{1011}$ and evidence of $\mathrm{T}$ cells reactive with islet components at the onset of diabetes are consistent with this hypothesis. ${ }^{12} 13$

Thus, type 1 diabetes is a disease of unknown aetiology, resulting from immune destruction of $\beta$ cells following environmental triggers occurring on a genetic background. As such it offers a paradigm in which twin studies may provide valuable information.

Rationale for studying identical twins with type 1 diabetes Studies in twins constitute a powerful technique for deciphering the relative contributions of 'nature' and 'nurture' in such a disease. Since type 1 diabetes has an immunological basis, many of our own studies have concentrated upon identifying immune abnormalities which characterise those twins who do, and those who do not, develop diabetes, and these will be the subject of this review. Differences between identical twins (discordance) must be due to non-genetic factors, while similarities indicate that a factor is inherited. Our recent studies have one general theme: to enrol twins after the diagnosis of diabetes in the cotwin; to collect blood samples prospectively; to analyse these at the end of the study, once twins have either become diabetic, or have little chance of doing so.

An important starting point in these studies has been to define those twins at high and low risk of developing diabetes after the diagnosis of their co-twin. In a population study of 49 twin pairs, non-diabetic twins were ascertained close to the development of diabetes in their co-twin. Most twins who developed diabetes did so within the first three years after diagnosis of the index twin, and all had done so by six years. ${ }^{5}$ Thus, such twins constitute a high disease risk group, and studying their immune system enables us to determine abnormalities which precede diabetes. Life table analysis of diabetes risk in non-diabetic twins identifies twins in whom the risk of developing diabetes is negligible. Twins remaining non-diabetic for more than six years after the diagnosis of their co-twin have a less than $2 \%$ chance of developing the disease. ${ }^{5}$ These twins constitute a genetically susceptible but low disease risk group. Studying immune changes in such twins should identify features which characterise 'diabetes resistance'. Comparison of abnormalities in the two groups enables the selection of those immune markers with the greatest predictive power for the disease. Our present series comprises 332 identical and 30 non-identical twin pairs in which the proband has diabetes. The twin study, started by Dr David Pyke, is now based at St Bartholomew's Hospital, London and twins have been collected and followed for up to 26 years.

\section{Immunological abnormalities in type 1 diabetes}

Several abnormalities, in both the cellular and humoral arms of the immune system, have been identified in newly diagnosed patients with type 1 diabetes in the last 20 years. Autoantibodies include islet cell antibodies, ${ }^{14}$ insulin autoantibodies, ${ }^{15}$ antibodies to a $64 \mathrm{kD}$ islet protein ${ }^{16}$ (now identified as the enzyme glutamic acid decarboxylase ${ }^{17}$ ), and antibodies to $50 \mathrm{kD}$ and $37 \mathrm{kD}$ tryptic fragments of islet proteins. ${ }^{18}$

Activated $\mathrm{T}$ lymphocytes, particularly those expressing CD8 (cytotoxic/suppressor phenotype), are typically present in the islet of Langerhans cellular infiltrate seen at diagnosis of type 1 diabetes. ${ }^{19}$ Islets from newly diagnosed diabetic patients are rarely accessible for study, but changes in circulating lymphocyte subsets of activation and function constitute some of the best characterised cellular immune abnormalities in type 1 diabetes. ${ }^{20}$ Circulating levels of 
activated $\mathrm{T}$ lymphocytes, expressing the class II HLA molecule HLA-DR ${ }^{1011}$ or the interleukin-2 receptor, ${ }^{21}$ are increased at diagnosis of type 1 diabetes, indicating involvement of the cellular immune system in the autoimmune responses, and paralleling the characteristics of the islet infiltrate.

Changes in the immune system associated with type 1 diabetes could result from the genetic susceptibility to the disease, the metabolic changes of diabetes, or be part of the immune process leading to. destruction of the islet $\beta$ cells. Twin studies enable us to discriminate between these possibilities. Since the 1970 s, we have followed up a cohort of non-diabetic twins, enrolled into the study soon after the diagnosis of diabetes in their co-twin. Prospective studies identify prediabetic and diabetes resistant twins so that the two groups can be compared.

\section{Studies on prediabetic twins: predicting the onset}

In a prospective study, following the design outlined and using a cohort of 20 twins of whom half became diabetic, immune abnormalities were highly prevalent in the prediabetic twins. ${ }^{22}$ Islet cell antibodies were detected in nine of the 10 prediabetic twins in the earliest sample analysed and persisted in eight until diagnosis of diabetes: if present, they tended to be of high titre. Cellular immune studies on the same cohort demonstrated that all prediabetic twins had high circulating levels of activated $\mathrm{T}$ cells in the first sample tested. $\mathrm{T}$ cell activation was increased in both the CD4 (helper/inducer) and CD8 (cytotoxic/suppressor) populations. ${ }^{23}$ As with islet cell antibodies, cellular activation persisted in nine of the 10 twins throughout the prediabetic period.

From a larger cohort of 58 twins, samples were obtained on a single occasion and analysed for the presence of antibodies to islet cells, glutamic acid decarboxylase, and the $\mathbf{5 0}$ and $37 \mathrm{kD}$ islet tryptic fragments. ${ }^{24}$ Twelve of the 58 twins became diabetic, and the majority of prediabetic twins (67$75 \%$ ) had each of these different antibodies and all 12 had at least one of the antibody specificities.

Thus, the characteristic of cellular and humoral immune abnormalities in the prediabetic period was the combinations of intensity, number and persistence. This provided a powerful predictor of diabetes in twins in that the presence of increased levels of activated $\mathrm{T}$ cells and islet cell antibodies or insulin autoantibodies detected on two consecutive occasions has a positive predictive value for diabetes of $100 \% .^{22}$

\section{Studies on twins remaining non-diabetic: identifying protection}

Twins remaining non-diabetic six years or more from the diagnosis of the index twin constitute a low risk group highly unlikely to develop diabetes. Interestingly, however, immune abnormalities, both cellular and humoral, were present in some of these twins..$^{22}$ In contrast to prediabetic twins, islet cell antibodies were detected in only three of the 10 twins during follow up and were transient and at low titres. Six of the 10 twins remaining non-diabetic also had increased levels of activated $T$ cells initially, but these were only detected on two further occasions during the follow up, that is, they did not persist. Analysis of the functional phenotype of the activated cells demonstrated a lack of activation in the CD8 population in contrast to prediabetic twins. ${ }^{23}$ In a larger cohort, in which 46 of 58 twins remained non-diabetic, antiglutamic acid decarboxylase, anti-50 kD, and anti-37 kD antibodies were detected in only $13 \%, 15 \%$, and $2 \%$ respectively. ${ }^{24}$

Protection from diabetes appears, therefore, to be conferred by default: twins remaining non-diabetic were characterised by the absence, low titre or transience of isletspecific antibodies, and the presence of activated $T$ cells of the helper, but not the cytotoxic phenotype.

\section{Significance of twin studies}

Twin studies such as these allow the identification of immune markers, detectable in the peripheral blood, which may predict the onset of the disease with considerable power, or equally indicate that a twin is safe from developing diabetes. These studies form a test bed for potential immune markers, some of which can be applied to population screening. Screening has become a desirable goal as the potential for therapeutic intervention, perhaps based on immunotherapy, to prevent diabetes has become a concrete possibility. ${ }^{25}$

In addition, twin studies have aided in defining the nature of the process which leads to type 1 diabetes. Our studies indicate that this process is initiated several months or years before the clinical diagnosis of diabetes. The destructive mechanisms, probably involving both activated CD4 and CD8 $\mathrm{T}$ lymphocytes, must persist in order to mediate irreparable islet damage. In contrast to immune responses to pathogens, this autoimmune response is less effective, taking several years to destroy its target. In some twins who remain disease free an immune response directed against the islets is also present, though this is mild and transient. Thus, the process leading to diabetes need not be an 'all-or-none' phenomenon. Further studies are required to determine the features of such diabetes resistance and, in particular, whether such a state can be induced in high risk individuals with persistent, high level cellular and humoral immune changes.

\section{Summary}

Diabetes is a multifactorial disease, the pathogenesis of which involves participation of the host immune system in $\beta$ cell destruction. Studies on identical twins offer the opportunity to define genetic and non-genetic factors which may contribute to susceptibility to the disease. Our own work indicates that the number and nature, as well as the intensity and persistence of immune abnormalities of cellular and humoral immune responses can be powerful predictors of the disease and also identify twins who have a degree of protection from the disease.

MARK PEAKMAN

Department of Immunology,

King's College School of Medicine and Dentistry,

Bessemer Road, London SE5 9PF

Department of Diabetes and Metabolism,

R DAVID G LESLIE

St Bartholomew's Hospital,

London ECIA 7BG

DIEGO VERGANI

\section{Department of Immunology,}

King's College School of Medicine and Dentistry, Bessemer Road, London SE5 9PF

Mark Peakman was a Wellcome Trust research training fellow during these studies, which were supported by the Wellcome Trust, Sir Jules Thorn Charitable Trust, British Diabetic Association, Joint Research Committee of King's College Hospital, and British Diabetic Twin Trust. If you know of a diabetic twin please contact Dr David Leslie at St Bartholomew's Hospital, West Smithfield, London EC1A 7BG.

1 Bingley PJ, Gale EAM. Incidence of insulin dependent diabetes in England: a study in the Oxford region, 1985-6. BMF 1989; 298: 558-60.

Bingley PJ, Gale EAM. Rising incidence of IDDM in Europe. Diabetes Care 1989; 12: 289-95.

Todd JA. Genetic control of autoimmunity in type 1 diabetes. Immunol Today

1990; 11: 122-8.

RYM, Hawa M, Leslie RDG. Studies of diabetic twins. Diabetes Metab Rev 1991; 7: 223-8.

5 Olmos P, A'Hern R, Heaton DA, Millward BA, Risley D, Pyke DA, Leslie 
RDG. The significance of the concordance rate for type 1 (insulindependent) diabetes in identical twins. Diabetologia 1988; 31:747-50.

6 Gepts W. The pathology of the pancreas in human diabetes. In: Andreani D, D Mario U, Federlin KF, Heding LG, eds. Immunology in diabetes. London: Kimpton Medical, 1984: 21-34.

7 Lernmark $\AA$. Islet cell antibodies. Diabetic Med 1987; 4: 285-92.

8 Johnston C, Alviggi L, Millward BA, Leslie RDG, Pyke DA, Vergani D. Alterations in T-lymphocyte subpopulations in type l diabetes: exploration Alterations in T-lymphocyte subpopulations in type l diabetes:

9 Smerdon RA, Peakman M, Hussain MJ, et al. Increase in simultaneous coexpression of naive and memory markers at diagnosis of insulin dependent diabetes mellitus. Diabetes 1992; 42: 127-33.

10 Alviggi L, Johnston C, Hoskins PJ, et al. Pathogenesis of insulin dependent diabetes: a role for activated T lymphocytes. Lancet 1984; ii: 4-5.

11 Peakman M, Hussain MJ, Millward BA, Leslie RDG, Vergani D. Effect of initiation of insulin therapy on T-lymphocyte activation in type 1 (insulin dependent) diabetes. Diabetic Med 1990; 7: 327-30

12 Roep BO, Aarden SD, De Vries RRP, Hutton JC. T-cell clones from a type-1 diabetes patient respond to insulin secretory granule proteins. Nature 1990; 345: $632-4$.

13 Roep BO, Kallan AA, Hazenbos WL, et al. T-cell reactivity to $38 \mathrm{kD}$ insulinsecretory granule protein in patients with recent-onset type 1 diabetes. Lancet 1991; 337: 1439-41.

14 Lendrum R, Walker GJ, Gamble DR. Islet cell antibodies in juvenile diabetes mellitus of recent onset. Lancet 1975; i: 880-3.

15 Greenbaum CJ, Palmer JP. Insulin antibodies and insulin autoantibodies. Diabetic Med 1991; 8: 97-105.

16 Baekkeskov S, Neilsen JH, Marner B, Bilde T, Ludvigsson J, Lernmark Å.
Autoantibodies in newly-diagnosed diabetic children immunoprecipitate human pancreatic islet cell proteins. Nature 1982; 298: 167-9.

17 Baekkeskov S, Aanstoot HJ, Christgau S, et al. Identification of the $64 \mathrm{~K}$ autoantigen in insulin-dependent diabetes as the GABA-synthesizing enzyme glutamic acid decarboxylase. Nature $1990 ; 347: 151-6$.

18 Christie MR, Vohra G, Champagne P, Daneman D, Delovitch TL. Distinct antibody specificities to a 64-kD islet cell antigen in type 1 diabetes as antibody specificities to a 64-kD islet cell antigen in type

19 Bottazzo GF, Dean BM, McNally JM, Mackay EH, Swift PGF, Gamble R. In situ characterization of autoimmune phenomena and expression of HLA molecules in the pancreas in diabetic insulitis. N Engl F Med 1985; 313: 353 60.

20 Peakman M, Vergani D. Cell-mediated immunity and type 1 diabetes. Diabetes Reviews 1992; 1: 5-8.

21 De Berardinis $\mathrm{P}$, Londei $\mathrm{M}$, Kahan $\mathrm{M}$, et al. The majority of the activated $\mathrm{T}$ cells in the blood of insulin-dependent diabetes mellitus (IDDM) patients are CD4+. Clin Exp Immunol 1988; 73: 255-9.

22 Leslie RDG, Tun RYM, Peakman $M$, et al. Persistent cellular and humora immune changes in the prediabetic period: a prospective twin study. Diabetologia 1992; 35 (suppl 1): A32.

23 Peakman M, Alviggi L, Hussain MJ, Pyke DA, Leslie RDG, Vergani D. Persistent T cell activation predicts diabetes in unaffected identical co-twins of type 1 diabetics. Diabetologia 34 (suppl 2): A56.

24 Christie MR, Tun RYM, Lo SSS, et al. Antibodies to GAD and tryptic fragments of islet $64 \mathrm{~K}$ antigen as distinct markers for development of IDDM Diabetes 1992; 41: 782-7.

25 Feldmann M, June CH, McMichael A, Maini R, Simpson E, Woody JN. T cell-targeted immunotherapy. Immunol Today 1992; 13: 84-5.

\section{Assessment of pancreatic exocrine function}

Impairment of pancreatic exocrine function in childhood is most commonly seen in association with cystic fibrosis but occurs in a range of different disorders.' Function may be assessed by aspiration of duodenal juice and measurement of enzymes secreted by the gland in response to stimulation by hormones or nutrients. Such stimulatory tests are intended to define whether or not the pancreas is diseased, abnormal secretions implying abnormal pancreas. There is, however, no clear agreement on what constitutes abnormal results.

Among the indications for pancreatic function testing are clinical suspicion of pancreatic insufficiency such as in the child with steatorrhoea and failure to thrive, the assessment of enzyme replacement therapy in a child with known pancreatic disease such as cystic fibrosis, and serial monitoring of function for example after pancreatitis or partial pancreatectomy. Alternatives to duodenal intubation include a number of indirect function tests. These are often easier to perform and rely upon analysis of enzymes in faeces or serum or investigation of how completely an administered test substance is digested. Indirect tests are usually based on the assessment of a single specific pancreatic enzyme; it is not always appropriate to make assumptions about other enzymes. For example, isolated enzyme deficiencies are well recognised, ${ }^{23}$ and in newborns and young infants there appears to be variation in the rates of development of individual pancreatic enzymes. ${ }^{4}$ In general, however, such tests when combined with clinical assessment are highly suitable for identifying those patients who require more detailed study. As pancreatic insufficiency is relatively uncommon in childhood it is important that an indirect test should reliably give a negative result in the absence of disease.

\section{Intraduodenal tests}

PANCREOZYMIN-SECRETIN TEST

The standard intraduodenal test involves stimulation of the pancreas with intravenous cholecystokinin (pancreozymin) followed by secretin. ${ }^{5}$ These specific intestinal peptides are used because they provide a powerful stimulus and appear to be important in normal control of pancreatic function. A simplified representation of their physiological role would be that secretin, released by acid in the duodenum, provides a bicarbonate rich secretion, while cholecystokinin released by the products of protein and fat digestion stimulates the production of a fluid rich in enzymes including trypsin, chymotrypsin, carboxypeptidase, pancreatic amylase, and lipases. Trypsin, released as inactive trypsinogen, changes spontaneously into its active form in solution, converting the other proteases into their active forms. This change is accelerated both by enterokinase secreted by enterocytes of the proximal small intestine, and the presence of activated trypsin. ${ }^{6}$ Pancreatic lipase is prevented from being denatured as a result of adsorption to the oil:water interface through being anchored by a colipase, a small protein also secreted by the pancreas.

During the test, secretin and cholecystokinin are given at an unphysiological dose of 2 units $/ \mathrm{kg}$ body weight with the aim of exciting the maximal possible response in the pancreas. Children in the first few months of life seem refractory to stimulation, probably because there are insufficient numbers of secretagogue receptors or receptor affinity is low. The total volume of secretions, bicarbonate output, lipase and amylase activities are measured together with one or more proteases ${ }^{7}$ and expressed in terms of output $/ \mathrm{kg}$ body weight $/ 50$ minutes of test. A correction for incomplete juice recovery can be made if a non-absorbable marker is perfused into the proximal duodenum and aspirated distally. ${ }^{8}$ The validity of this test refinement which adds greatly to an already technically complex procedure has not been clearly established. Enzyme analysis should be performed without delay, but addition of glycerol $(50 \% \mathrm{v} / \mathrm{v})$ and storage at $-20^{\circ} \mathrm{C}$ will stabilise lipase and trypsin for at least a month. Although reference ranges for stimulated duodenal juice have been published for children, ${ }^{7}$ problems in standardising analysis of enzymes make comparisons between laboratories extremely difficult. Ideally, stimulation tests should only be performed in a centre with its own reference ranges. Normal amylase and lipase activities with low protease activity should suggest congenital enterokinase deficiency. ${ }^{9}$ Addition of enterokinase to a sample of duodenal fluid causes a marked increase in tryptic activity. 